\title{
CULTURAL AND SOCIO-SYSTEMOLOGICAL MODEL OF PRINCIPLES OF SOCIOLOGY OF GENDER CULTURE OF UKRAINE AND UNDERSTANDING OF ITS SUBJECT: ACCORDING TO THE RESULTS OF THE DOCTORAL DISSERTATION
}

\author{
Yuriy Romanenko \\ Doctor of Sociology, Professor at the Department of International Media Communications \\ and Communication Technologies, Institute of International Relations, \\ Taras Shevchenko National University of Kyiv, Ukraine \\ e-mail: romanenko.jura@gmail.com,orcid.org/0000-0001-6395-4395
}

Ivan Svyatnenko

Candidate of Sociological Sciences, Ukraine

e-mail: magellan4x4@ukr.net, orcid.org/0008-0006-5896-6273

\section{Summary}

The aim of the article is to build a cultural and socio-systemic model of the principles of sociology of gender culture of Ukraine and understanding its subject (gender culture of Ukraine) as a meaningful totality with specific value-standardizing axiospheres and regulators of dominance / submissiveness relations between different gender groups.

Based on the author's (cultural and socio-systemic) approach, the definition of gender culture as a structured subsystem of culture and axiosphere formation, which includes centering, verticalizing, ordinalizing and materializing levels with appropriate elements, was formulated. Gender culture is a subsystem of meaning-making, which occurs at the level of centering, the formation of axial forms of value consciousness, which form higher axiostasis of gender: gender center, gender mission, hierarchy of gender identities, gender worldview, gender orientation, gender hierarchy of values gender character, gender scripts and gender norms (goal setting patterns). At the level of gender centralizer, mission and identity, images of the gender absolute are formed, which becomes a starting point in the sacralization and desecration of certain gender groups (centralizer), life activity program (mission) and constellation of essential features (gender dispositions). At the level of gender worldview, orientation, hierarchy of values, gender-role hierarchy, a gender picture of the social world with its key actors, vectors of activity of these actors and their hierarchy (status-role niches) is formed. At the level of gender, gender scripts and goal-setting patterns, personalized carriers of gender types, scenarios of their behavior and models of their achievement are formed.

Keywords: gender culture, gender culture of Ukraine, cultural and socio-systemic model, gender centralizer, gender mission, gender identities, gender worldview, gender scripts, gender inculturation and socialization.

DOI: https://doi.org/10.23856/3875

\section{Introduction}

Ukrainian society has its own gender culture, built on special relations of micro-government and micro-dependence. The core of this gender culture is femininocentrism, which in religion is revealed as feminolatry and maternolatry, in philosophy as cardiocentrism and affectocentrism, in ideology as hidden matriarchal racism, in social morality as materialism 
and matriarchy (matriarchy). All these components are elements of both the cultural system in general and gender culture in particular. The study of gender culture is carried out in the sociology of gender and the sociology of gender culture as a subdivision of the sociology of gender. At the same time, both the study of the sociology of gender and the sociology of gender culture as middle-level theories requires an appropriate theoretical and methodological superstructure, which forms the knowledge of the highest level of generalization.

In the study of this knowledge of the highest level of generalization identified cultural and social systemology. Cultural and social systemology as a neofunctionalist metatheory of cultural and social systems has a developed conceptual and categorical apparatus that allows the study of gender theory and gender practices (Sviatnenko, 2016: 76-81; 69-74).

Currently, the relevance of the topic in the scientific and theoretical sense arises in connection with the typological uncertainty of the sociology of gender culture of Ukraine as a sectoral sociological theory of the middle level, which allows to distinguish gender culture of Ukraine among gender cultures of other societies.

First of all, there are certain theoretical paradoxes that outline the contradictions of its basic features in cultural and social systemology, namely: 1) theoretical uncertainty of the center of gender culture of Ukraine and related missions and identities of key gender groups; 2) insufficient certainty of the gender worldview (its philosophical, ideological, moral and social components), orientations and value hierarchies; 3 ) the difficulty of building a model of status-role hierarchies of key gender and gender groups as subjects of research in the sociology of gender culture; 4) theoretical uncertainty of gender features, gender scripts (scenarios) and gender norms.

The aim of the article is to build a cultural and socio-systemic model of the principles of sociology of gender culture of Ukraine and understanding its subject (gender culture of Ukraine) as a meaningful totality with specific value-standardizing axiospheres and regulators of dominance / submissiveness relations between different gender groups and mechanisms through mechanisms of gender inculturation and socialization (Sviatnenko, 2016: 112-116).

An analysis of recent research and publications in which the scientific problem was initiated associated with the works of Yu. Romanenko (Romanenko, 2016: 140-220), which highlights the principles of cultural and social systemology as a neo-functionalist metatheory of cultural and social systems, and the author's articles published in professional journals of Ukraine (Sviatnenko, 2016: 116-120).

\section{Gender centralizer and gender missions}

Building a theoretical model of the subject of the article is a deductive process of ascent from the general to the specific. Specific in this case is the subject of sociology of gender culture as a branch sociological theory of the middle level in the context of applying the conceptual apparatus of cultural and social systemology to understand gender culture as one of the spheres of cultural system in its relationship with the social system.

The cultural system in cultural and social systemology is considered as one of the registers of the tetracluster, the components of which, along with the cultural and social system, are also the psyche and the body. In this regard, it is necessary to clarify the relationship and interaction of gender culture as a subsystem of the cultural system not only with the social system, but also with the mind and body / corporeality.

There are four levels in the register of the cultural system, which are distinguished in cultural and social systemology according to the principle of recursion (through isomorphic 
representation). These are "culture in culture", "society in culture", "psyche in culture" and "body in culture".

The elements of "culture in culture", as the author deals with gender culture, are the gender center, gender mission (submission) and gender identity. According to the logic of cultural and social systemology, they do not represent any autonomous entities, but are extensions of the centralizer, mission, hierarchy of identities of Ukraine as a society.

The centralizer is a complex formation that contains a hierarchy of subordinate axiospheres, subordinate spheres of value consciousness: religion, philosophy, ideology, social morality, law. The centralizer as a structure can be formed with the participation of all these axiospheres, and with certain of their "gaps" (value backlashes) (Svyatnenko, 2019: 35-44).

At the same time, as a structure that is centrifugal, and therefore time- and space-forming, the concentrator essentially coincides with the image of sacred primordial reality (religion), world-order (including social world and order of life) (philosophy), reduced axiology (key doctrines) institutions, social groups and their hierarchies (ideology), informal and formalized regulators of good behavior (morality and law).

The center of gender culture in Ukraine is the religious and mythological image of the great Amazon mother as a gender absolute. The image itself is syncretic, combining features of the Christian image of the Mother of God and the great mother (the warrior goddess), popular in pagan cultures. basic sexual groups - women and men.

Because the gender image of the great Amazon mother is a contradictory combination of feminine and masculine (gender-split) traits, it becomes dominant and primary-referential in the formation of men's missions and identities as submissive (subordinate) to women with pronounced femininity. Women in gender culture set and define men's missions, and men obey women in defining their (men's) missions. Thus, women are mission-forming and men are submissive to women (Sviatnenko, 2016: 60-66; 76-81).

In the gender culture of Ukraine there is a discrepancy between the verbal-declarative and socio-practical levels. This means that the declared missions of men do not coincide with their actual missions. The declared missions of men are voiced as the main and leading, but in fact they are dependent and secondary to women, who set them their life programs and appointments.

\section{Gender identities}

Split splitters and missions are recursively reproduced in split (feminine-masculine) identities of women and split (masculine-feminine) identities of men.

In the study, such identities were defined as latent-transfigured. They are a variety of culturally and socially transfigured gender identities that differ from biologically transfigured identities in the preservation of primary sexual characteristics in men and women. Thus, men's gender identities are transfigured, split, quasi-feminine.

This means that gender identities instilled in men in the processes of gender inculturation and socialization do not coincide with their biological sex, because in gender culture they are attributed feminine traits. The range of such feminine traits includes: passivity, patience, silence, tolerance for inconvenience, obedience, receptivity (predominance of receptivity over active understanding), executive (propensity to perform, high level of performance discipline) (Sviatnenko, 2019: 53-56; 60-61).

On the contrary, women's gender identities are transfigured, split, quasi-masculine. This means that gender identities instilled in women in the processes of inculturation and socialization 
do not coincide with their biological sex, because in gender culture they are attributed masculine traits. The range of such masculine traits includes: activity, intolerance, tendency to detailed verbal manifestations, intolerance of inconvenience, disobedience (pride, arrogance).

As a result, we get a society of gender-deficient women with a lack of femininity and socio-role overload and gender-deficient men with a lack of masculinity and socio-role mismatch.

\section{Gender worldview}

At the level of gender worldview, there is a recursion of split gender identities in the version of maternal-centrism / femininocentrism, which expresses at the same time the characteristics of traditional-maternal and emancipated-rationalist life in which rational / masculine in gender order is subordinated to feminine / emotional. The feminine is at the center of the gender (social) world, while the masculine forms its background (context). For gender culture in general, this means that in the world of gender relations, masculine men are tertiary actors compared to feminine men and women (Svyatnenko, 2016: 112-116).

\section{Gender orientation}

Gender orientation is a recursion of the gender worldview. This means that the feminine determines the vectors of movement (cultural, social, mental and physical) for the masculine.

In gender practices, this means the dominance of undirected movement over directed (undirected over directed) through the subordination of the masculine / masculine to the feminine / feminine and the childish / infantile. In fact, this is manifested in the determination of a man's orientation through the matriarchal nuclear family (through the setting of the vectors of a man's movement by women and children), which is specified in the comprehensive service of women's and children's projects (Sviatnenko, 2019: 53-56; 60-61).

\section{Gender hierarchies of values}

At the level of the hierarchy of values, non-directionality is recursively reproduced in the destruction of the hierarchy and its replacement by a hierarchy of values. This is reflected in the gender practices of the subordination of the masculine principle in its career-adaptive roles to family values, the content of which is close to everyday life and consumerism. Men's budgets of time, which according to the theory of cultural and social systemology determine value hierarchies, become completely subject to women's regulation.

The hierarchies of values of men and women also record the inequality of self-realization and leisure and career activities. The former prevail in the value choices of the female part of the sample, the second - in the male part. Thus, women prioritize the values of self-realization and leisure, while men prioritize careers and work (Svyatnenko, 2019: 35-44).

Thus, the hierarchy of values reveals the matriarchal dominance of women, because the dominant cultural group in society is one that has larger time budgets for self-development and recreation. Men, as a gender group that has to pursue career growth and employment, is a group dependent on women. At the same time, the verbal-declarative level does not coincide with the social-factual one. The importance of career and work for men is proclaimed in society, however, in gender culture, they are less valuable compared to self-development and leisure (Svyatnenko, 2019: 35-44). 


\section{Status-role hierarchies of gender groups}

At the level of the status-role hierarchy of gender groups, the relations of open hierarchies are replaced by the relations of apparent equality while maintaining latent hierarchies. At the same time, there is a mismatch between declarative and actual gender relations. Declared gender relations are defined as relations of gender equality, while real (actual) gender relations are relations of subordination of men to women and children. In general, the status-role (status-group) hierarchy of relations between gender groups is as follows.

\section{Gender character}

At the level of gender, the status-role hierarchy is recursively reproduced in the form of psychopathic-megalomaniacal character in women as a gender group and passive-feminine psychopathy with elements of narcissistic deficiency and masochistic self-destructiveness in men as a gender group. Types of characters are reflected in the discourse of everyday consciousness (self-perception of women) as images of supervaluable (angolized) individuals, men - as ordinary or devalued.

The theoretical model of women's characters is described through the signs of power-loving (kratophilia), persistence, purposefulness, authoritarianism, pragmatism, behavioral rigidity, demanding, propensity to use volitional pressure.

The theoretical model of masculinity is described through signs of female-dependent self-esteem, sensitivity to reflections of women (both from the microsocial environment and from unfamiliar environment), childishness, propensity to instrumental behavior (gender servility) towards women, self-destructive victim behavioral traits towards women and children.

On the other hand, despite the polar characteristics, gender expectations of women and men are contradictory and incompatible with their biological sex. This contradiction stems, in particular, from the incompatibility of the requirements for male aggression, strength and power, on the one hand, and flexibility, softness, tolerance for deprivation, on the other. Matriarchal gender culture contains the same contradictory views on women: they must be restrained, disciplined, persistent and soft, gentle, sensual, and so on. Such discrepancies are recursively reproduced at the level of gender scripts of masculinity and femininity (Sviatnenko, 2016: 60-66; Sviatnenko, 2017: 22-26; 35-40; Svyatnenko).

\section{Gender scripts}

Gender scripts of women and men are defined in terms of subordination of different areas of activity of feminized-psychopathic, narcissistic-deficient and masochistic-self-destructive men to megalomaniacal-psychopathic women. Women are the leaders, while men are the leaders in all areas of their lives. They are more responsive to women's initiatives than active. This applies to all spheres of men's life: economic activity, choice of residence, upbringing of children, choice of profession and strategy of professional self-realization, etc (Svyatnenko, 2019: 35-44).

\section{Gender norms}

Gender norms as standards for assessing achievement are defined in the framework of gender scripts. For example, the gender script "male friendship" is normatively assessed as latent biological homosexuality (if men are close friends, they are more likely to be gay). 
Hence, the norm for men's relationships becomes homophobia, and for women heterophobia (men, according to the gender norms of gender culture of Ukraine should be afraid of other men, treat them with caution, etc., while women should show respect for each other friendly interest, mutual assistance, mutual support, etc.) (Svyatnenko, 2019: 85-94).

In Ukraine's gender culture, dual gender norms / standards for assessing male and female behavior are typical: what is considered the norm in men's behavior is set by women. On the other hand, men have no influence on the establishment of gender norms in the female gender environment. Men, therefore, are not allowed to determine the norm and deviation for women. On the contrary, women can define the boundaries of what is allowed and what is not allowed for men (Sviatnenko, 2017: 17-22; 35-40).

\section{Conclusions}

Based on the author's (cultural and socio-systemic) approach, the definition of gender culture as a structured subsystem of culture and axiosphere formation, which includes centering, verticalizing, ordinalizing and materializing levels with appropriate elements, was formulated. Gender culture is a subsystem of meaning-making, which occurs at the level of centering, the formation of axial forms of value consciousness, which form higher axiostasis of gender: gender center, gender mission, hierarchy of gender identities, gender worldview, gender orientation, gender hierarchy of values gender character, gender scripts and gender norms (goal setting patterns). At the level of gender centralizer, mission and identity, images of the gender absolute are formed, which becomes a starting point in the sacralization and desecration of certain gender groups (centralizer), life activity program (mission) and constellation of essential features (gender dispositions). At the level of gender worldview, orientation, hierarchy of values, gender-role hierarchy, a gender picture of the social world with its key actors, vectors of activity of these actors and their hierarchy (status-role niches) is formed. At the level of gender, gender scripts and goal-setting patterns, personalized carriers of gender types, scenarios of their behavior and models of their achievement are formed.

\section{References}

Grigaliunaite V., Pileliene L. (2017). Consumer attention online: How to be visible? Central European Business Review, 6 (4), 30-44. https://doi.org/10.18267/J.CEBR.189 (Scopus)

Greblikaite J., Sroka W., Gerulaitiene N. (2016). Involving young people in polish and lithuanian social enterprises by fostering entrepreneurial skills and abilities as entrepreneurial opportunity at university. Entrepreneurial Business and Economics Review, 4 (3), 131-152. https://doi.org/10.15678/EBER.2016.040310 (Scopus)

Greblikaite J. (2017). Social entrepreneurship in rural development of Lithuania: Potential of young entrepreneurs. In Advances in Business and Management, 14, 207-230. https://doi.org/10.15544/mts.2017.12 (Scopus)

Capay M., Drlik M., Svec P., Tomanova J., Romaniukha M., Sorokina L. (2016). Attitudes and Expectations on Virtual Environments of the Universities. 11 International Scientific Conference on Distance Learning in Applied Informatics. Sturovo, Slovakia, 273-284. https://publons.com/p/7372502/ (Web of Science)

Klochko M., Serdyuk A., Golovko O., Syniavska O. (2016). On the fringes: Female prisoners in Ukraine: Are they unique? In Lives of Incarcerated Women: An International Perspective (pp. 47-70). Taylor and Francis Inc. (Web of Science) https://publons.com/publon/9815154/ 
Klymenko E. (2019). Die Schwächsten der Schwachen Ukraine: Kinder im Krieg [The weakest of the weak Ukraine: children at war]. Osteuropa, 69 (3-4). https://www.zeitschrift-osteuropa. de/hefte/2019/3-4/die-schwaechsten-der-schwachen/?productId=24807\&variationId=0\&productTitle $=$ Die + Schw $\%$ C3\%A4chsten + der + Schwachen\&qty $=1 \&$ totalQty $=1 \&$ numberOfTitles $=1 \&$ totalAmount $=3 \% 2 \mathrm{C00} \% \mathrm{C} 2 \% \mathrm{A0} \% \mathrm{E2} \% 82 \% \mathrm{AC}$ (Scopus)

Klymenko E. (2017). Analysis of the state of the leading sectors of the economy in Donbass for the old industrial region - summer-autumn 2014th. Baltic Journal of Economic Studies, 3 (4), 107-114. https://publons.com/p/3397737/(Web of Science)

Nechyporenko V. V., Bocheliuk V. I., Pozdniakova-Kyrbiatieva E. G., Pozdniakova O. L., Panov N. S. (2019). Value foundation of the behavior of managers of different administrative levels: Comparative analysis. Espacios, 40(34). http://ww.revistaespacios.com/ a19v40n34/19403417.html (Scopus)

Omelyanenko V., Semenets-Orlova I., Khomeriki O., Lyasota L., Medviedieva Y. (2018). Technology transfer management culture (education-based approach). Problems and Perspectives in Management, 16 (3), 454-463. https://doi.org/10.21511/ppm.16(3).2018.36 (Scopus) https://www.scopus.com/sourceid/19700170105

Sviatnenko, I. O. (2016). Henderna kultura yak sotsiolohichnyi kontsept: do postanovky problemy [Hrani : naukovo-teoretychnyi i hromadsko-politychnyi almanakh]. Dnipro : Hrani. [in Ukrainian].

Sviatnenko, I. O. (2016). Kulturno-tsinnisni skladnyky ukrainskoi hendernoi kultury v sotsiosystemolohichnomu vymiri [Hrani : naukovo-teoretychnyi i hromadsko-politychnyi almanakh]. Dnipro : Hrani. [in Ukrainian].

Sviatnenko, I.O. (2016). Androtsydarnyi matriarkhat $v$ instrumentarii hendernoi kultury Ukrainy [Hrani : naukovo-teoretychnyi almanakh]. Dnipro : Hrani. [in Ukrainian].

Sviatnenko, I. O. (2016). Tsinnisna svidomist yak rehistr panuvannia i dominuvannia $v$ hendernykh kulturakh: sotsiosystemolohichnyi aspekt [Hrani : naukovo-teoretychnyi almanakh]. Dnipro : Hrani [in Ukrainian].

Sviatnenko, I. O. (2017). Nasylstvo v hendernii kulturi: problema pobudovy typolohii (chastyna 1) [Hrani : naukovo-teoretychnyi almanakh]. Dnipro : Hrani. [in Ukrainian].

Sviatnenko, I. O. (2017). Nasylstvo v hendernii kulturi: problema pobudovy typolohii (chastyna 2) [Hrani : naukovo-teoretychnyi almanakh]. Dnipro : Hrani. [in Ukrainian].

Sviatnenko, I. O. (2017). Deviatsii v ukrainskii hendernii kulturi: sotsiosystemolohichnyi aspekt [Hrani : naukovo-teoretychnyi almanakh]. Dnipro : Hrani. [in Ukrainian].

Svyatnenko, I. (2019). Reculiarities of valuable hierarchization and gender identities of men and women [Sotsialni tekhnolohii: aktualni problemy teorii ta praktyky]. Zaporizhzhia : KPU. [In English].

Svyatnenko, I. (2019). Gender xenophobia: candidate gender behavior in a love and preliminary period [Hrani : naukovo-teoretychnyi almanakh] Dnipro : Hrani. [In English].

Sviatnenko, I. (2019). Fenomen sakralizatsii materynstva v ukrainskii hendernii kulturi: chynnyky i mozhlyvi naslidky [Sotsialne prohnozuvannia ta proektuvannia maibutnoho krainy: problemy myra ta nenasylstva $v$ zminakh hlobalnoho poriadku] Zaporizhzhia : KSK-Alians. [in Ukrainian].

Sviatnenko, I. O. (2019). Mizandriia i homofobiia v hendernii kulturi Ukrainy [Prydniprovski sotsiolohichni chytannia] Dnipro: Vydavnycho-polihrafichnyi dim "Format A+". [in Ukrainian]. 